\title{
Molecular Characterization of Ovarian Yolk Sac Tumor (OYST)
}

\author{
Khalil Hodroj ${ }^{1, *}{ }^{\mathbb{C}}$, Aleksandra Stevovic ${ }^{2}$, Valery Attignon ${ }^{1}$, Domenico Ferraioli ${ }^{1}$, Pierre Meeus ${ }^{1}$, \\ Sabrina Croce ${ }^{3}$, Nicolas Chopin ${ }^{1}$, Lea Rossi ${ }^{1}$, Anne Floquet ${ }^{3}$, Christine Rousset-Jablonski ${ }^{1}$, Olivier Tredan ${ }^{1}$, \\ Frédéric Guyon ${ }^{3}$, Isabelle Treilleux ${ }^{1}$, Corinne Rannou ${ }^{1}$, Marie Morfouace ${ }^{2}$ and Isabelle Ray-Coquard ${ }^{1}$ (D)
}

check for

updates

Citation: Hodroj, K.; Stevovic, A.; Attignon, V.; Ferraioli, D.; Meeus, P.; Croce, S.; Chopin, N.; Rossi, L.;

Floquet, A.; Rousset-Jablonski, C.; et al. Molecular Characterization of Ovarian Yolk Sac Tumor (OYST).

Cancers 2021, 13, 220.

https://doi.org/10.3390/

cancers 13020220

Received: 27 November 2020

Accepted: 7 January 2021

Published: 9 January 2021

Publisher's Note: MDPI stays neutral with regard to jurisdictional clai$\mathrm{ms}$ in published maps and institutional affiliations.

Copyright: $\odot 2021$ by the authors. Licensee MDPI, Basel, Switzerland. This article is an open access article distributed under the terms and conditions of the Creative Commons Attribution (CC BY) license (https:// creativecommons.org/licenses/by/ $4.0 /)$.
1 Centre Léon Berard (CLB), 69008 Lyon, France; Valery.Attignon@lyon.unicancer.fr (V.A.); Domenico.Ferraioli@lyon.unicancer.fr (D.F.); pierre.meeus@lyon.unicancer.fr (P.M.); nicolas.chopin@lyon.unicancer.fr (N.C.); lea.rossi@lyon.unicancer.fr (L.R.); christine.rousset-jablonski@lyon.unicancer.fr (C.R.-J.); olivier.tredan@lyon.unicancer.fr (O.T.); isabelle.treilleux@lyon.unicancer.fr (I.T.); corinne.rannou@lyon.unicancer.fr (C.R.); isabelle.ray-coquard@lyon.unicancer.fr (I.R.-C.)

2 EORTC, Translational Research, 1200 Brussels, Belgium; aleksandra.stevovic@eortc.org (A.S.); marie.morfouace@eortc.org (M.M.)

3 Institut Bergonié, 33000 Bordeaux, France; s.croce@bordeaux.unicancer.fr (S.C.); a.floquet@bordeaux.unicancer.fr (A.F.); F.Guyon@bordeaux.unicancer.fr (F.G.)

* Correspondence: Khalil.hodroj@lyon.unicancer.fr

Simple Summary: Ovarian yolk sac tumors (OYSTs) are rare and specific therapeutic strategies are needed after the failure of platinum-based first-line and salvage regimens. This retrospective study included ten patients with OYST, including patients with relapsed disease and disease-free patients. Three patients (33.3\%) harbored oncogenic mutations in KRAS, KIT and ARID1A, which may be used as a target. Our series shows that relapsed patients with molecular analysis had clinically relevant molecular alterations. Future research with dedicated trials and multicenter international collaborations are needed to demonstrate the efficacy of specific therapeutic strategies after failure of platinum-based first-line and salvage regimens.

Abstract: Most patients with malignant ovarian germ cell tumors (MOGTCs) have a very good prognosis and chemotherapy provides curative treatment; however, patients with yolk sac tumors (OYSTs) have a significantly worse prognosis. OYSTs are rare tumors and promising results are expected with the use of specific therapeutic strategies after the failure of platinum-based first-line and salvage regimens. We initiated a project in collaboration with EORTC SPECTA, to explore the molecular characteristics of OYSTs. The pilot project used retrospective samples from ten OYST relapsed and disease-free patients. Each patient had a molecular analysis performed with FoundationOne CDx describing the following variables according to the Foundation Medicine Incorporation (FMI): alteration type (SNV, deletion), actionable gene alteration, therapies approved in EU (for patient's tumor type and other tumor types), tumor mutational burden (TMB), and microsatellite instability (MSI) status. A total of 10 patients with OYST diagnosed between 2007 and 2017 had a molecular analysis. A molecular alteration was identified in four patients (40\%). A subset of three patients (33.3\% of all patients) harbored targetable oncogenic mutations in KRAS, KIT, ARID1A. Two patients at relapse harbored a targetable mutation. This retrospective study identifies clinically relevant molecular alterations for all relapsed patients with molecular analysis. Dedicated studies are needed to demonstrate the efficacy of specific therapeutic strategies after the failure of platinum-based first-line and salvage regimens and to explore the potential relationship of a molecular alteration and patient outcome.

Keywords: OYST; molecular characteristics; targetable mutation; patient outcome 


\section{Introduction}

Malignant germ cell tumors (MGCTs) represent 5\% of all ovarian cancers and $80 \%$ of the pre-adolescent malignant ovarian tumors. Most patients with ovarian germ cell tumors will be cured with first-line therapy, with five-year overall survival rates of $95.6 \%$ and $73.2 \%$ in stage I and advanced stages, respectively [1].

The malignant ovarian GCTs (mOGCTs) are assumed to derive from primordial germ cells (PGCs) with inherited or somatically acquired alterations [2]. PGCs may be identified in human embryos at 5-6 weeks of gestational age. Orchestrated by the KIT ligand (KITLG, also known as the stem cell factor, SCF) and its receptor KIT, and the chemokine SDF1 (CXCL12) and its receptor CXCR4, PGCs migrate from the proximal epiblast (yolk sac) through the hindgut and mesentery to the genital ridge and become gonocytes [3,4]. Level of gene expression and appropriate timing of expression are crucial to appropriately control the process.

The primitive GCTs are subdivided into the ovarian counterpart of the male testicular seminoma, dysgerminoma (DG), and non-DGs. The development of non-DGs is characterized by differentiation into cell histologies that mimic embryonic tissues (embryonal carcinoma (EC), teratoma) and extraembryonic tissues (yolk sac tumor (YST) or non-gestational choriocarcinoma (CC)) (Figure 1) [2].

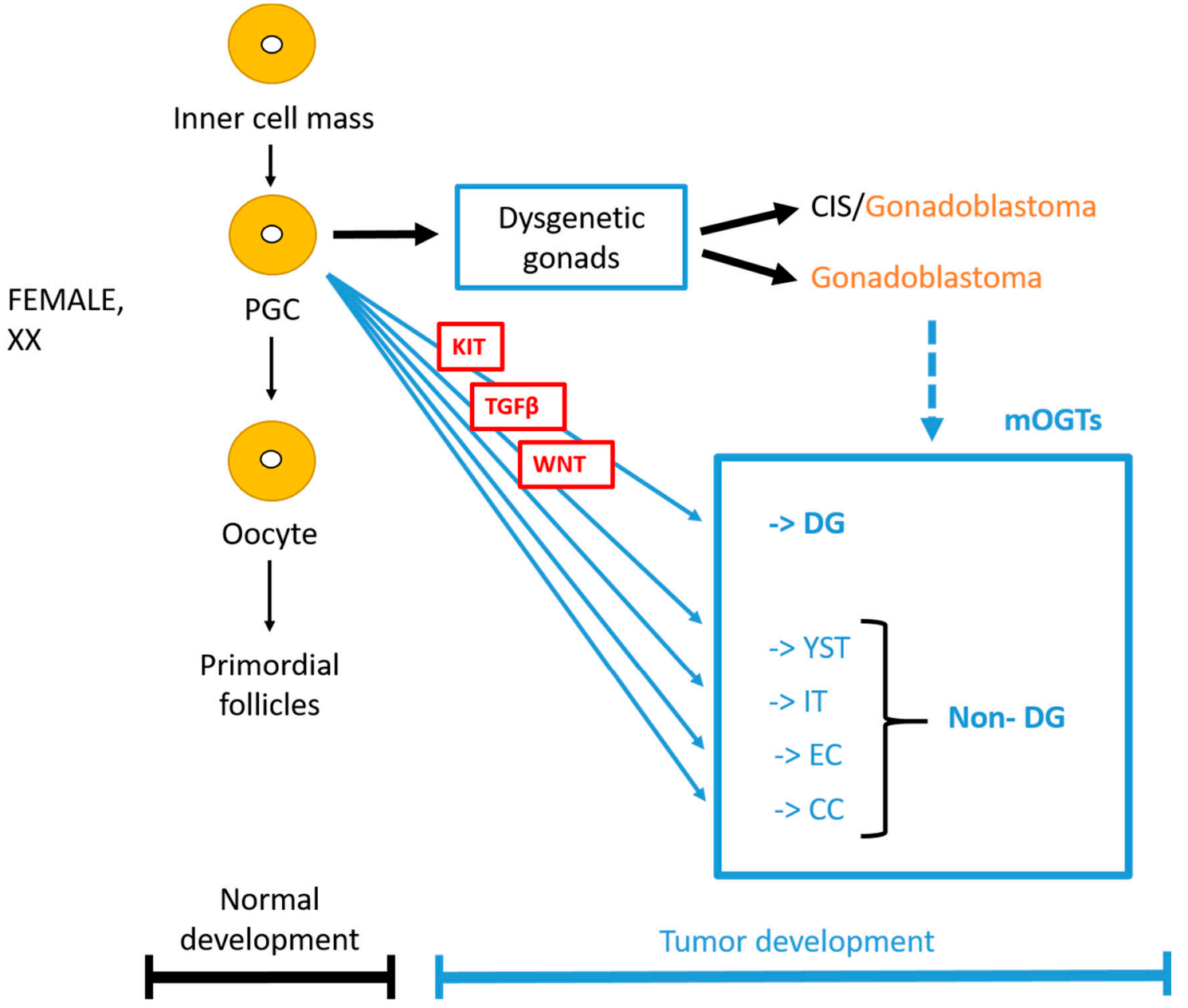

Figure 1. Illustration of germ cell tumor (GCT) development. CC: choriocarcinoma; CIS: carcinoma in situ; DG: dysgerminoma; EC: embryonal carcinoma; IT: immature teratoma; mOGCT: malignant ovarian GCT; PGC: primordial germ cell; YST: yolk sac tumor. 
Ovarian yolk sac tumors (OYSTs) have the worst prognosis among MOGCTs [5]. Specific therapeutic strategies after the failure of platinum-based first-line and salvage regimens are needed. Risk factors for recurrence are stage (greater than I), age (older than 45 years) and management of treatment in non-referral centers [6].

Comprehensive knowledge of molecular biology might help to better understand the pathogenesis, the risk of relapse, and the development of potential innovative therapies [7]. However, only a few dedicated molecular investigation concern mOGCT.

Most therapeutic progress emerged from experience acquired in the treatment of testicular NSGCTs. However, some gender-specific molecular characteristics may be expected. In testicular GCTs, molecular structures amenable to targeted treatment approaches have been identified, and many of the available targeting agents have shown promising activity in vitro [8]. However, until today, results of preclinical models have rarely been translated into a benefit in clinical practice [9].

A national network for the rare ovarian tumors was created in 2011, supported by the French National Cancer Institute (INCa). This network provides diagnostic expertise and aims to improve the care of patients with these rare tumors using referral multidisciplinary tumor boards. It also facilitates recruitment for trials dedicated to only rare cancers with international effort [10,11].

In this context, in collaboration with EURACAN and EORTC SPECTA, we developed a project to better understand the molecular landscape of rare cancers. Here we focus on patients with OYSTs, who had been sequenced during the pilot phase of this project using retrospective samples; considering relapsed and disease-free patients.

\section{Results}

\subsection{Population}

A total of 10 patients with a yolk sac tumor diagnosed between 2007 and 2017 were selected, and their characteristics are presented in Table 1 . Five patients $(50 \%)$ were FIGO stage Ia, two (20\%) stage IIIc and three (30\%) were stage IV. Median age at diagnosis was 28 years (range 17-52). Nine patients had an oophorectomy and one patient had a radical surgery (bilateral salpingo-oophorectomy, total abdominal hysterectomy, omentectomy and lymphadenectomy) following a misdiagnosis initially identifying an ovarian high-grade serous carcinoma; this patient received a first cycle with carboplatin and paclitaxel. Nine out of ten received adjuvant bleomycin, etoposide, cisplatin (BEP)-based chemotherapy. Four patients (57\%) planned to have four cycles of chemotherapy had their last cycle without bleomycin. Three patients relapsed, one of them was cured with a first-line salvage regimen, one died two years after the diagnosis after many lines of chemotherapy, and one progressed after first-line treatment and died (Tables 2 and 3).

\subsection{Molecular Characteristics and Abnormalities}

Clinically significant alterations identified are presented in Table 4. Molecular analysis failed for one sample (patient \#5). A gene alteration was identified in four out of nine profiled patients' tumors. Three patients (33.3\% of all patients) had potentially targetable activating mutations in KRAS, KIT and ARID1A. Patient \#4 had seven concomitant mutations (KRAS G12V, CCND2, FGF23, FGF6, and KDM5A amplification, KIT D816A, ARID1A Q538). All 9 tested patients were MSI stable/low. Low tumor mutational burden (TMB) was identified for all of them, reporting a median of 3 mutations per megabase (Mut/MB) (range 0-5 Mut/MB). According to the FMI reports, treatment based on TMB score is only recommended for patients with $10 \mathrm{Mut} / \mathrm{MB}$ or more. Patient \#7 had a CRKL amplification. Patient \#10 had a KRAS D33E mutation. 
Table 1. Patient characteristics.

\begin{tabular}{ccccc}
\hline $\begin{array}{c}\text { Patient } \\
\text { Number }\end{array}$ & $\begin{array}{c}\text { Age at Diagnosis } \\
\text { (Year) }\end{array}$ & Medical History & Histology & $\begin{array}{c}\text { Stage FIGO } \\
\text { at Diagnosis }\end{array}$ \\
\hline 1 & $37 \mathrm{y}$ & None & YST & Ia \\
\hline 2 & $37 \mathrm{y}$ & None & YST & IIIc \\
\hline 3 & $25 \mathrm{y}$ & None & YST & IIIc \\
\hline 4 & $27 \mathrm{y}$ & None & YST, first misdiagnosed as ovarian high \\
grade serous carcinoma & IVb \\
\hline 5 & $52 \mathrm{y}$ & None & YST & Ia \\
\hline 7 & $29 \mathrm{y}$ & None & IVa \\
\hline 9 & $20 \mathrm{y}$ & None & YST + mucinous cystadenoma \\
\hline 10 & $35 \mathrm{y}$ & Polycystic ovary & syndrome & Ia \\
\hline
\end{tabular}

Description of patient characteristics at diagnosis with FIGO stage and initial localization. YST: Yolk sac tumor.

Table 2. Patient initial treatment.

\begin{tabular}{|c|c|c|c|c|}
\hline Patient Number & $\begin{array}{c}\text { Surgery } \\
\text { (Oophorectomy (A) vs. } \\
\text { Radical Surgery (B)) }\end{array}$ & $\begin{array}{c}\text { Adjuvant } \\
\text { Chemotherapy }\end{array}$ & $\begin{array}{c}\text { Response to First Line } \\
\text { Treatment }\end{array}$ & Relapse \\
\hline 1 & A & 4 cycles of BEP & Complete response & No \\
\hline 2 & $\mathrm{~A}$ & $4 \mathrm{BEP}$ & Complete response & No \\
\hline 3 & A & $3 \mathrm{BEP}, 1 \mathrm{EP}$ & Complete response & No \\
\hline 4 & A & $3 \mathrm{BEP}, 1 \mathrm{EP}$ & Complete response & No \\
\hline 5 & B & $\begin{array}{l}1 \text { cycle of Carboplatin } \\
\text { paclitaxel then } 3 \text { cures } \\
\text { of BEP }\end{array}$ & Progression & $\begin{array}{l}\text { Died } 1 \text { month after the } \\
\text { end of chemotherapy }\end{array}$ \\
\hline 6 & A & $3 \mathrm{BEP}$ & Complete response & No \\
\hline 7 & A & $4 \mathrm{BEP}$ & Complete response & No \\
\hline 8 & A & $3 \mathrm{BEP}, 1 \mathrm{EP}$ & Complete response & No \\
\hline 9 & A & 3 BEP 1 EP & Complete response & $\begin{array}{l}\text { Relapsed after } 5 \text { year: } \\
\text { aFP elevation and } \\
\text { abdominal pain (one } \\
\text { peritoneal node). }\end{array}$ \\
\hline 10 & Bilateral oophorectomy & No & Complete response & $\begin{array}{c}\text { Elevation of aFP } 6 \\
\text { months after first } \\
\text { surgery. Lesion of the } \\
\text { upper bowel and iliac } \\
\text { lymph node. Died } 2 \\
\text { years after diagnosis }\end{array}$ \\
\hline
\end{tabular}

Description of initial treatment including type of surgery, chemotherapy, and initial response to treatment. BEP: Bleomycin, Etoposide, Cisplatin. EP: Etoposide, Cisplatin Radical surgery (B) involves bilateral salpingo-oophorectomy, total abdominal hysterectomy, omentectomy and lymphadenectomy. 
Table 3. Treatment at relapse.

\begin{tabular}{|c|c|c|c|c|}
\hline Patient Number & $\begin{array}{c}\text { Treatment after First } \\
\text { Relapse }\end{array}$ & $\begin{array}{l}\text { Response to } \\
\text { Treatment }\end{array}$ & Other Treatment & Last News \\
\hline 9 & $\begin{array}{l}2 \text { ICE with autologous } \\
\text { stem cell injection }\end{array}$ & Complete response & No & $\begin{array}{c}\text { Complete response } \\
(12 / 2019)\end{array}$ \\
\hline 10 & $3 \mathrm{BEP}, 1 \mathrm{EP}$ & $\begin{array}{l}\text { Progression with } \\
\text { peritoneal carcinosis } \\
\text { and spleen metastasis } \\
\text { before surgery of } \\
\text { residual active mass }\end{array}$ & $\begin{array}{c}3 \text { VeIP } \\
\text { docetaxel/gemcitabine ( } 4 \\
\text { cycles) } \\
\text { adriamycin/ } \\
\text { cyclophosphamid/ avastin } \\
\text { ( } 2 \text { cycles) } \\
\text { carboplatin/ paclitaxel (1 } \\
\text { cycle) } \\
\text { endoxan/affinitor (1 cycle) }\end{array}$ & $\begin{array}{l}\text { Died } 2 \text { year after } \\
\text { diagnosis }\end{array}$ \\
\hline
\end{tabular}

Description of treatment at relapse and outcomes. BEP: Bleomycin, Etoposide, Cisplatin. ICE: Ifosfamide, Carboplatin, Etoposide. VeIP: Vinblastine, Ifosfamide, Cisplatin.

Table 4. Molecular characteristics.

\begin{tabular}{|c|c|c|c|c|c|c|c|c|}
\hline $\begin{array}{l}\text { Patient } \\
\text { ID }\end{array}$ & $\begin{array}{c}\text { Alteration } \\
\text { Type }\end{array}$ & $\begin{array}{l}\text { Alteration: } \\
\text { Gene }\end{array}$ & $\begin{array}{c}\text { MSI } \\
\text { Status }\end{array}$ & $\begin{array}{l}\text { TMB } \\
\text { Status }\end{array}$ & $\begin{array}{c}\text { TMB } \\
\text { Muts/MB }\end{array}$ & $\begin{array}{c}\text { Actionable } \\
\text { Alteration } \\
+\end{array}$ & Potential Therapies & $\begin{array}{c}\text { Potential } \\
\text { Therapies } \\
\circ\end{array}$ \\
\hline 1 & None & None & Stable & Low & 3 & None & None & \\
\hline 2 & None & None & Stable & Low & 3 & None & None & \\
\hline 3 & None & None & Stable & Low & 0 & None & None & \\
\hline \multirow{7}{*}{4} & $\begin{array}{l}\mathrm{SNV}+\text { am- } \\
\text { plification }\end{array}$ & $\begin{array}{l}\text { KRAS } \\
\text { G12V am- } \\
\text { plification }\end{array}$ & & & & $\begin{array}{l}\text { KRAS } \\
\text { G12V am- } \\
\text { plification }\end{array}$ & $\begin{array}{l}\text { Binimetinib, Cobime- } \\
\text { tinibTrametinib }\end{array}$ & \\
\hline & amplification & $\begin{array}{l}\text { CCND2 am- } \\
\text { plification }\end{array}$ & Stable & Low & 0 & None & None & \\
\hline & amplification & $\begin{array}{l}F G F 23 \text { am- } \\
\text { plification }\end{array}$ & & & & None & None & \\
\hline & amplification & $\begin{array}{l}\text { FGF6 am- } \\
\text { plification }\end{array}$ & & & & None & None & \\
\hline & amplification & $\begin{array}{l}\text { KDM5A } \\
\text { amplifica- } \\
\text { tion }\end{array}$ & & & & None & None & \\
\hline & SNV & KIT D816A & & & & KIT D816A & $\begin{array}{l}\text { dasatinib, Imatinib, } \\
\text { Nilotinib, Ponatinib, } \\
\text { Sorafenib, Sunitinib, } \\
\text { binimetinib, } \\
\text { cobimetinib, } \\
\text { trametinib }\end{array}$ & $\begin{array}{l}\text { ripretinib, } \\
\text { avapritinib }\end{array}$ \\
\hline & SNV & $\begin{array}{l}\text { ARID1A } \\
\text { Q538* }\end{array}$ & & & & ARIDA1 & None & olaparib \\
\hline 5 & Failed & Failed & Failed & Failed & Failed & Failed & Failed & \\
\hline 6 & None & None & stable & Low & 5 & None & None & \multirow{5}{*}{ olaparib } \\
\hline 7 & amplification & $\begin{array}{l}\text { CRKL am- } \\
\text { plification }\end{array}$ & stable & Low & 4 & None & None & \\
\hline 8 & None & ARID1A & Stable & Low & 4 & None & None & \\
\hline 9 & rearrangement & $\begin{array}{l}\text { rearrange- } \\
\text { ment exon } \\
19\end{array}$ & stable & Low & 0 & ARID1A & None & \\
\hline 10 & SNV & $\begin{array}{l}\text { KRAS } \\
\text { D33E }\end{array}$ & Stable & Low & 4 & $\begin{array}{l}\text { KRAS } \\
\text { D33E }\end{array}$ & $\begin{array}{l}\text { binimetinib, } \\
\text { cobimetinib, } \\
\text { trametinib }\end{array}$ & \\
\hline
\end{tabular}

Description of clinically significant variants for each patient based on the FMI report. TMB: tumor mutational burden. * Specific therapies targeting this molecular alteration in other cancer types. ${ }^{+}$molecular alteration for which clinical or preclinical evidence of predictive benefit from a specific therapy (in any cancer type) from FMI report. ${ }^{\circ}$ Potential therapy not included in FMI report [12,13]. 
Two of three patients with relapse had an oncogenic targetable mutation (ARID1A and $K R A S)$. Among disease-free patients after first-line treatment, two out of seven harbored molecular alterations with one being targetable.

\section{Discussion}

This retrospective study reports results from 10 patients with YST diagnosed between 2007 and 2017. A complete response was observed for nine patients (90\%) after first-line treatment. However, three patients relapsed (30\%), one reported a complete response after HDCT, one patient died two years after diagnosis and one died one month after first line treatment.

Germ cell tumors are remarkably chemosensitive, and despite the high cure rates with initial and salvage chemotherapy, there remains a cohort of germ cell tumor patients who will eventually succumb to their progressive malignancy. New therapeutic agents are still needed for this patient population.

We report the molecular characteristics of nine YST patients with successful molecular analysis leading to potentially targetable oncogenic mutations identified for three patients (33.3\% of all patients) in KRAS, KIT and ARID1A. Actionability is defined as a molecular alteration for which there is clinical or preclinical evidence of a predictive benefit from a specific therapy (in any cancer type). Interestingly, we were able to identify clinically relevant molecular alterations for all relapsed patients (patient \#9 and \#10).

The main limitations of this study are the reduced sample size of our series and failure of molecular analysis for the patient with the poorest prognosis (patient \#5). Dedicated studies are needed to confirm these results and to study benefit from specific therapeutic strategies after the failure of platinum-based first-line and salvage regimens. Additionally, further research should be done to tackle the correlation between the presence of a molecular alteration and the patients' outcome.

Among mOGCTs, mutations in KIT have been previously identified exclusively in dysgerminoma (DG) at frequencies of $27 \%$ (6 of 22) and $24 \%$ (4 of 17), whereas no mutations have been reported in tumors of patients with pure or mixed histologies of IT and YST $[14,15]$. The success of KIT-targeting imatinib mesylate in the treatment of GIST [16] and chronic myelogenous leukemia [17] may be relevant for DG treatment [18]. However, a small trial investigating imatinib mesylate in patients with KIT-positive metastatic TGCT $(n=6)$ did not result in remission for any patient [19]. This phase II study defined KIT positivity by IHC as $>10 \%$ of stained cells for KIT and the type of mutation was not defined. All previously reported mutations in DG were located in KIT exon 17 (D816V, D816H, and D816Y). Mutations in KIT activation loop (A-loop), including D816, have been reported to confer preclinical and clinical resistance to imatinib and sunitinib in GIST [20,21]. KIT exon 17 mutations, including D816, were reported to be sensitive to avapritinib [12].

In our cohort, patient \#four had a KIT D816A mutation, but also a KRAS G12V hotspot mutation with amplification, CCND2, FGF23, FGF6, and KDM5A amplification, and ARID1A Q538* stop mutation. Among these mutations, three are actionable alterations (KIT D816A, KRAS G12V and ARID1A Q538*) with targeted therapies available. KRAS encodes a member of the RAS family of small GTPases and activating mutations in $R A S$ can cause uncontrolled cell proliferation and tumor formation [22]. Preclinical evidence suggests that KRAS activation may predict sensitivity to MEK inhibitors, such as trametinib and cobimetinib tested in colorectal cancer [23].

ARID1A encodes a subunit of several different SWI/SNF protein complexes. SWI/SNF complexes regulate gene activity by a process known as chromatin remodeling. ARID1A is also recruited to DNA double-strand breaks (DSB) via its interaction with the upstream DNA damage checkpoint kinase ATR [24]. Tumors with this mutation may exhibit therapeutic vulnerability to PARP inhibitors according to preclinical results [13].

The other alterations are involved in cell growth and no targeted therapies directly address these genomic alterations. FGF6 and FGF23 encode a member of the fibroblast growth factor protein family with a role in muscle tissue regeneration and phosphate 
homeostasis, respectively. CCND2 encodes Cyclin D2, which contributes to the regulation of the cell cycle G1-S transition. KDM5A encodes a lysine-specific histone demethylase that potentiates the expression of genes involved in cellular proliferation, senescence, angiogenesis, and migration.

All analyzed patients were microsatellite stable (MSS) and had a low TMB (median $3 \mathrm{Mut} / \mathrm{MB}$, range $0-5 \mathrm{Mut} / \mathrm{MB}$ ). The role of immune checkpoint inhibitors should be analyzed in these rare tumors. However, preliminary results from two studies investigating pembrolizumab and avelumab in male GCTs did not show significant efficacy $[25,26]$. Low immune infiltrate is associated with a poorer patient outcome in TGCT and improved knowledge in the tumor microenvironment may help for the development of immunotherapeutic strategies $[27,28]$.

The YSTs often display complex and varied histological appearance, making differential diagnosis difficult, in particular between YST and endometroid or clear-cell carcinoma of the ovary. In our cohort, one patient has an initial misdiagnosis identifying high-grade serous carcinoma. A central pathology review confirmed the diagnosis of YST. Diagnosis of rare cancer is critical and may be challenging, and expert pathological review is recommended [11,29].

\section{Materials and Methods}

\subsection{Eligibility Criteria and Data Collection}

In collaboration with EURACAN and EORTC SPECTA, data and samples were collected as per hospital policy. Patients signed a specific hospital consent to allow the use of their samples for future research, including genomic analysis, according to The International Council for Harmonization of Technical Requirements for Pharmaceuticals for Human Use (ICH) and applicable national laws. Two hospitals participated in the pilot phase of the Arcagen project: patients were seen at Centre Léon Berard (CLB), Lyon, France and Institut Bergonie, Bordeaux, France. We retrospectively identified a series of 10 patients with a yolk sac tumor (YST) in our database and reviewed their clinical, radiological, histological, and molecular characteristics. Selection criteria included good quality tumor blocs at initial diagnosis, diagnosis before 2017 and signed informed consent available for research. All available patients were analyzed and no additional selecting criteria were used.

\subsection{Pathology Review}

The ESMO guidelines were used as a standard for diagnosis to ensure consistency. All cases were examined by an expert pathologist in the diagnosis of YST as per ESMO guidelines through the national network for the rare ovarian tumors.

\subsection{Sample Workflow and Molecular Analyses}

Samples were sent to the Foundation Medicine lab (Penzberg, Germany). The molecular analysis was performed using FoundationOne CDx. A single DNA extraction method from routine FFPE biopsy or surgical resection specimens, and 50-1000 ng underwent whole-genome shotgun library construction and hybridization-based capture. Using an Illumina ${ }^{\circledR}$ HiSeq platform, hybrid capture-selected libraries were sequenced to high uniform depth. For each patient, the following variables are described in the molecular report provided by FMI: alteration type (SNV, deletion, amplification, fusion), alteration name, actionable gene alteration, therapies approved in EU (patient tumor type and other tumor types), tumor mutational burden (TMB) and microsatellite instability (MSI) status.

Actionability was defined as a molecular alteration for which there is clinical or preclinical evidence of a predictive benefit from a specific therapy (in any cancer type).

\subsection{Regulatory Aspects}

Patients signed a specific hospital consent to allow the use of their samples for future research, including genomic analysis, according to The International Council for Harmoni- 
sation of Technical Requirements for Pharmaceuticals for Human Use (ICH) and applicable national laws. Data collections were in accordance with Act $N^{\circ} 78-17$ of 6 January 1978 on Data Processing, Data Files and Individual Liberties.

\section{Conclusions}

This study is the first part of the new research program (prospective SPECTA), exploring rare gynecological tumor molecular alterations and potential therapies. It highlights the feasibility to perform such molecular analysis in the routine for rare cancer settings but these results are very preliminary with a low sample size, and molecular analysis failed for one out of three patients who died.

Due to the lack of molecular evidence in rare tumors, other programs are needed with clinical trials and studies dedicated to better understanding rare gynecological tumor molecular profile and pathogenesis. Future analysis should also include RNA sequencing and phosphoprotein assessments.

Author Contributions: Conceptualization, I.R.-C. and M.M.; formal analysis, K.H., A.S., V.A., M.M. and I.R.-C.; writing—original draft preparation, K.H., M.M. and I.R.-C.; writing—review and editing, all authors. All authors have read and agreed to the published version of the manuscript.

Funding: This research received no external funding.

Institutional Review Board Statement: The study was conducted according to the guidelines of the Declaration of Helsinki, and approved by the French CPP (Ethical review board) in 07/2019, under the number 2019-074B.

Informed Consent Statement: Informed consent was obtained from all subjects involved in the study.

Data Availability Statement: The data presented in this study are available within the article in Tables 1-4. No other data were created or analyzed.

Conflicts of Interest: The authors declare no conflict of interest.

\section{References}

1. Gatta, G.; van der Zwan, J.M.; Casali, P.G.; Siesling, S.; Dei Tos, A.P.; Kunkler, I.; Otter, R.; Licitra, L.; Mallone, S.; Tavilla, A.; et al. Rare cancers are not so rare: The rare cancer burden in Europe. Eur. J. Cancer 2011, 47, 2493-2511. [CrossRef] [PubMed]

2. Kraggerud, S.M.; Hoei-Hansen, C.E.; Alagaratnam, S.; Skotheim, R.I.; Abeler, V.M.; Rajpert-De Meyts, E.; Lothe, R.A. Molecular Characteristics of Malignant Ovarian Germ Cell Tumors and Comparison With Testicular Counterparts: Implications for Pathogenesis. Endocr. Rev. 2013, 34, 339-376. [CrossRef] [PubMed]

3. Sheikine, Y.; Genega, E.; Melamed, J.; Lee, P.; Reuter, V.E.; Ye, H. Molecular genetics of testicular germ cell tumors. Am. J. Cancer Res. 2012, 2, 153-167. [PubMed]

4. Honecker, F.; Stoop, H.; Mayer, F.; Bokemeyer, C.; Castrillon, D.H.; Lau, Y.-F.C.; Looijenga, L.H.J.; Oosterhuis, J.W. Germ cell lineage differentiation in non-seminomatous germ cell tumours. J. Pathol. 2006, 208, 395-400. [CrossRef]

5. Mangili, G.; Sigismondi, C.; Gadducci, A.; Cormio, G.; Scollo, P.; Tateo, S.; Ferrandina, G.; Greggi, S.; Candiani, M.; Lorusso, D. Outcome and Risk Factors for Recurrence in Malignant Ovarian Germ Cell Tumors: A MITO-9 Retrospective Study. Int. J. Gynecol. Cancer 2011, 21, 1414-1421. [CrossRef]

6. Nasioudis, D.; Chapman-Davis, E.; Frey, M.K.; Caputo, T.A.; Holcomb, K. Management and prognosis of ovarian yolk sac tumors; an analysis of the National Cancer Data Base. Gynecol. Oncol. 2017, 147, 296-301. [CrossRef]

7. Galvez-Carvajal, L.; Sanchez-Muñoz, A.; Ribelles, N.; Saez, M.; Baena, J.; Ruiz, S.; Ithurbisquy, C.; Alba, E. Targeted treatment approaches in refractory germ cell tumors. Crit. Rev. Oncol./Hematol. 2019, 143, 130-138. [CrossRef]

8. Oing, C.; Kollmannsberger, C.; Oechsle, K.; Bokemeyer, C. Investigational targeted therapies for the treatment of testicular germ cell tumors. Expert Opin. Investig. Drugs 2016, 25, 1033-1043. [CrossRef]

9. Manchana, T.; Ittiwut, C.; Mutirangura, A.; Kavanagh, J.J. Targeted therapies for rare gynaecological cancers. Lancet Oncol. 2010, 11, 685-693. [CrossRef]

10. Ray-Coquard, I.; Trama, A.; Seckl, M.J; Fotopoulou, C.; Pautier, P.; Pignata, S.; Kristensen, G.; Mangili, G.; Falconer, H.; Massuger, L.; et al. Rare ovarian tumours: Epidemiology, treatment challenges in and outside a network setting. Eur. J. Surg. Oncol. 2019, 45, 67-74. [CrossRef]

11. Gershenson, D.M.; Okamoto, A.; Ray-Coquard, I. Management of Rare Ovarian Cancer Histologies. JCO J. Clin. Oncol. 2019, 37, 2406-2415. [CrossRef] [PubMed]

12. Evans, E.K.; Gardino, A.K.; Kim, J.L.; Hodous, B.L.; Shutes, A.; Davis, A.; Zhu, X.J.; Schmidt-Kittler, O.; Wilson, D.; Wilson, K.; et al. A precision therapy against cancers driven by KIT/PDGFRA mutations. Sci. Transl. Med. 2017, 9, eaao1690. [CrossRef] [PubMed] 
13. Park, Y.; Chui, M.H.; Rahmanto, Y.S.; Yu, Z.-C.; Shamanna, R.A.; Bellani, M.; Gaillard, S.; Ayhan, A.; Viswanathan, A.; Seidman, M.; et al. Loss of ARID1A in tumor cells renders selective vulnerability to combined ionizing radiation and PARP inhibitor therapy. Clin. Cancer Res. 2019, 25, 5584-5594. [CrossRef] [PubMed]

14. Hoei-Hansen, C.E.; Kraggerud, S.M.; Abeler, V.M.; Kærn, J.; Rajpert-De Meyts, E.; Lothe, R.A. Ovarian dysgerminomas are characterised by frequent KIT mutations and abundant expression of pluripotency markers. Mol. Cancer 2007, 6, 12. [CrossRef] [PubMed]

15. Cheng, L.; Roth, L.M.; Zhang, S.; Wang, M.; Morton, M.J.; Zheng, W.; Abdul Karim, F.W.; Montironi, R.; Lopez-Beltran, A. KIT gene mutation and amplification in dysgerminoma of the ovary. Cancer 2011, 117, 2096-2103. [CrossRef]

16. Corless, C.L.; Barnett, C.M.; Heinrich, M.C. Gastrointestinal stromal tumours: Origin and molecular oncology. Nat. Rev. Cancer 2011, 11, 865-878. [CrossRef]

17. Eiring, A.M.; Khorashad, J.S.; Morley, K.; Deininger, M.W. Advances in the treatment of chronic myeloid leukemia. BMC Med. 2011, 9, 99. [CrossRef]

18. Pedersini, R.; Vattemi, E.; Mazzoleni, G.; Graiff, C. Complete response after treatment with imatinib in pretreated disseminated testicular seminoma with overexpression of c-KIT. Lancet Oncol. 2007, 8, 1039-1040. [CrossRef]

19. Einhorn, L.H.; Brames, M.J.; Heinrich, M.C.; Corless, C.L.; Madani, A. Phase II Study of Imatinib Mesylate in Chemotherapy Refractory Germ Cell Tumors Expressing KIT. Am. J. Clin. Oncol. 2006, 29, 12-13. [CrossRef]

20. Gajiwala, K.S.; Wu, J.C.; Christensen, J.; Deshmukh, G.D.; Diehl, W.; DiNitto, J.P.; English, J.M.; Greig, M.J.; He, Y.-A.; Jacques, S.L.; et al. KIT kinase mutants show unique mechanisms of drug resistance to imatinib and sunitinib in gastrointestinal stromal tumor patients. Proc. Natl. Acad. Sci. USA 2009, 106, 1542-1547. [CrossRef]

21. Heinrich, M.C.; Maki, R.G.; Corless, C.L.; Antonescu, C.R.; Harlow, A.; Griffith, D.; Town, A.; Mckinley, A.; Ou, W.-B.; Fletcher, J.A.; et al. Primary and Secondary Kinase Genotypes Correlate With the Biological and Clinical Activity of Sunitinib in ImatinibResistant Gastrointestinal Stromal Tumor. JCO J. Clin. Oncol. 2008, 26, 5352-5359. [CrossRef]

22. Pylayeva-Gupta, Y.; Grabocka, E.; Bar-Sagi, D. RAS oncogenes: Weaving a tumorigenic web. Nat. Rev. Cancer 2011, 11, 761-774. [CrossRef] [PubMed]

23. Yeh, J.J.; Routh, E.D.; Rubinas, T.; Peacock, J.; Martin, T.D.; Shen, X.J.; Sandler, R.S.; Kim, H.J.; Keku, T.O.; Der, C.J. KRAS/BRAF mutation status and ERK1/2 activation as biomarkers for MEK1/2 inhibitor therapy in colorectal cancer. Mol. Cancer Ther. 2009, 8, 834-843. [CrossRef] [PubMed]

24. Shen, J.; Peng, Y.; Wei, L.; Zhang, W.; Yang, L.; Lan, L.; Kapoor, P.; Ju, Z.; Mo, Q.; Shih, I.-M.; et al. ARID1A Deficiency Impairs the DNA Damage Checkpoint and Sensitizes Cells to PARP Inhibitors. Cancer Discov. 2015, 5, 752-767. [CrossRef] [PubMed]

25. Adra, N.; Einhorn, L.H.; Althouse, S.K.; Ammakkanavar, N.R.; Musapatika, D.; Albany, C.; Vaughn, D.; Hanna, N.H. Phase II trial of pembrolizumab in patients with platinum refractory germ-cell tumors: A Hoosier Cancer Research Network Study GU14-206. Ann. Oncol. 2018, 29, 209-214. [CrossRef] [PubMed]

26. Mego, M.; Svetlovska, D.; Chovanec, M.; Rečkova, M.; Rejlekova, K.; Obertova, J.; Palacka, P.; Sycova-Mila, Z.; De Giorgi, U.; Mardiak, J. Phase II study of avelumab in multiple relapsed/refractory germ cell cancer. Investig. New Drugs 2019, 37, 748-754. [CrossRef] [PubMed]

27. Lobo, J.; Rodrigues, Â.; Guimarães, R.; Cantante, M.; Lopes, P.; Maurício, J.; Oliveira, J.; Jerónimo, C.; Henrique, R. Detailed Characterization of Immune Cell Infiltrate and Expression of Immune Checkpoint Molecules PD-L1/CTLA-4 and MMR Proteins in Testicular Germ Cell Tumors Disclose Novel Disease Biomarkers. Cancers 2019, 11, 1535. [CrossRef] [PubMed]

28. Siska, P.J.; Johnpulle, R.A.N.; Zhou, A.; Bordeaux, J.; Kim, J.Y.; Dabbas, B.; Dakappagari, N.; Rathmell, J.C.; Rathmell, W.K.; Morgans, A.K.; et al. Deep exploration of the immune infiltrate and outcome prediction in testicular cancer by quantitative multiplexed immunohistochemistry and gene expression profiling. Oncoimmunology 2017, 6, e1305535. [CrossRef]

29. Chiannilkulchai, N.; Pautier, P.; Genestie, C.; Bats, A.; Vacher-Lavenu, M.; Devouassoux-Shisheboran, M.; Treilleux, I.; Floquet, A.; Croce, S.; Ferron, G.; et al. Networking for ovarian rare tumors: A significant breakthrough improving disease management. Ann. Oncol. 2017, 28, 1274-1279. [CrossRef] 